\title{
Pengembangan Bahan Ajar dengan Pendekatan Induktif untuk Meningkatkan Kemampuan Representasi Matematis Siswa SMP
}

\author{
Indri Puspandari ${ }^{*}$, Ena S. Praja ${ }^{2}$, dan Fahrudin Muhtarulloh ${ }^{3}$ \\ 1*,2Program Studi Pendidikan Matematika, Universitas Swadaya Gunung Jati \\ Jalan Pemuda No. 32, Cirebon, Jawa Barat, Indonesia \\ 1indripuspandari193@gmail.com, 2suhenaena@yahoo.co.id, \\ ${ }^{3}$ Program Studi Pendidikan Matematika, Universitas Islam Negeri Sunan Gunung Djati \\ Jalan A.H. Nasution No.105, Bandung, Jawa Barat, Indonesia \\ 3 fahrudinmuhtar.math@gmail.com
}

Artikel diterima: 02-03-2019, direvisi: 27-05-2019, diterbitkan: 31-05-2019

\begin{abstract}
Abstrak
Kemampuan representasi matematis berkontribusi terhadap prestasi belajar matematika. Di lapangan kemampuan representasi matematis masih rendah. Penelitian ini dilakukan untuk mengembangkan bahan ajar berupa modul dengan pendekatan induktif pada materi persamaan linear satu variabel untuk siswa kelas VII SMP/MTs, mengetahui learning obstacle (hambatan belajar) pada materi persamaan linear satu variabel, mengetahui kevalidan dari modul dan pedoman pembelajaran guru, serta apakah terdapat peningkatan sesudah menggunakan modul ini. Penelitian ini menggunakan model pengembangan ADDIE (Analysis, Design, Development, Implementation, and Evaluation), tetapi dibatasi hanya sampai tahap ADD dan diujicobakan secara terbatas pada kelas VII SMP Negeri 1 Tengahtani. Instrumennya adalah soal tes kemampuan representasi matematis, lembar pedoman wawancara, lembar validasi modul dan lembar validasi pedoman pembelajaran guru. Hasil penelitian menunjukkan bahwa terdapat learning obstacle saat dilakukan uji coba soal. Kemampuan representasi matematis siswa mengalami peningkatan dengan rata-rata sebesar 0,37 yang berarti nilai tersebut memiliki interpretasi sedang.

Kata kunci: ADDIE, kemampuan representasi matematis siswa, pendekatan induktif.
\end{abstract}

\section{Development of Teaching Materials with an Inductive Approach to Enhance the Capability of Mathematical Representation of Middle School Students}

\begin{abstract}
The ability of mathematical representation contributes to mathematics learning achievement. In the field, the ability of mathematical representation is still low. This research was conducted to develop teaching materials in the form of modules with an inductive approach to one variable linear equation material for class VII SMP / MTs students, to know the learning obstacle in one variable linear equation material, to know the validity of teacher learning modules and guidelines, and is there an increase after using this module. This study uses the ADDIE development model (Analysis, Design, Development, Implementation, and Evaluation), but is limited only to the ADD stage and is tested on a limited basis in class VII Tengahtani 1 Public Middle School. The instruments are test questions of mathematical representation abilities, interview guideline sheets, module validation sheets, and teacher learning guideline validation sheets. The results showed that there was a learning obstacle when testing the problem. The ability of mathematical representation of students has increased with an average of 0.37 which means that the value has a moderate interpretation.

Keywords: ADDIE, students' mathematical representation ability, inductive approach.
\end{abstract}

Volume 8, Nomor 2, Mei 2019

Copyright $\odot$ 2019Mosharafa: Jurnal Pendidikan Matematika 


\section{Pendahuluan}

Pada pembelajaran di SMP, matematika mempunyai peranan yang sangat penting dalam mengembangkan kemampuan siswa khususnya kemampuan representasi matematis (Ramziah, 2016). Pentingnya kemampuan representasi dalam pembelajaran matematika pada jenjang sekolah sudah di tetapkan oleh NCTM. NCTM (Effendi, 2012) menetapkan bahwa standar representasi pada progam pembelajaran dari pra-taman kanak-kanak sampai kelas 12 harus memungkinkan siswa untuk: (1) Menciptakan dan menggunakan representasi untuk mengordinisir, mencatat, dan mengomunikasikan ide-ide matematis; (2) Memilih, menerapkan, dan mengartikan representasi matematis untuk memecahkan masalah; dan (3) Menggunakan representasi untuk memodelkan dan menginterpretasikan fenomena fisik, sosial, dan fenomena matematis. Oleh karena itu, kemampuan representasi matematis diperlukan pada proses belajar siswa sehingga dapat berpikir dan mengomunikasikan ide-ide matematis lalu menetapkan ide-ide matematis itu yang sifatnya abstrak menuju nyata untuk memecahkan masalah matematika agar lebih mudah dipahami khususnya untuk siswa SMP Negeri 1 Tengahtani.

Hutagaol (2013) mengatakan bahwa kemampuan representasi matematis yang dihasilkan oleh siswa merupakan ungkapan-ungkapan matematika dari suatu gagasan atau ide matematika yang 308 dimunculkan siswa dalam pemikirannya untuk memahami suatu konsep matematika ataupun dalam tindakannya untuk mencari suatu solusi dari masalah matematika yang sedang dihadapinya. Oleh karena itu, kemampuan representasi matematis adalah salah satu kemampuan matematika yang berpengaruh pada kognitif siswa sehingga berkaitan dengan hasil belajar matematika siswa. Mandur (2013) menunjukan bahwa hasil dari penelitiannya pada kemampuan representasi matematis berkontribusi sebesar 9,42\% terhadap prestasi belajar matematika baik secara langsung maupun tidak langsung. Peneliti melakukan observasi kepada 30 siswa kelas VII SMP Negeri 1 Tengahtani dan menunjukan bahwa hasil dari kemampuan representasi matematis siswa SMP Negeri 1 Tengahtani masih rendah.

Hasil jawaban dari salah satu siswa kelas VII SMP Negeri 1 Tengahtani disajikan pada gambar 1. Pada gambar 1 terlihat siswa belum dapat menyelesaikan soal tersebut dengan menentukan contoh variabel, koefisien, konstanta, dan suku. Hambatan pada pelajaran ini terjadi karena siswa tidak dapat memahami pengertian dari variabel, koefisien,

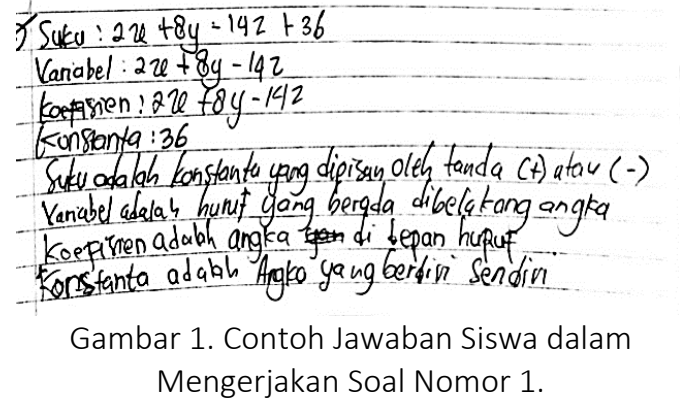

Mosharafa: Jumal Pendidikan Matematika Volume 8, Nomor 2, Mei 2019 Copyright $\odot$ 2019Mosharafa: Jurnal Pendidikan Matematika 
konstanta dan suku pada bentuk aljabar.

Setelah itu, peneliti juga melakukan wawancara tanya jawab dengan guru matematika SMP Negeri 1 Tengahtani. Berdasarkan hasil wawancara dapat diperoleh bahwa siswa dan siswi di SMP Negeri 1 Tengahtani mengalami kendala dalam belajar matematika di sekolahnya. Mereka selalu beranggapan bahwa matematika itu sangat sulit, pelajaran yang tidak disukai dan menakutkan. Ferdianto (2015) juga berpendapat bahwa siswa masih menggangap matematika sebagai pelajaran yang tidak menyenangkan dan membosankan. Kondisi seperti ini terjadi selain dari siswanya sendiri, dari guru juga berpengaruh dalam menyampaikan materi matematika di kelas. Terkadang materi matematika yang disampaikan kurang bisa dipahami oleh siswanya. Berdasarkan wawancara tersebut diketahui bahwa metode yang sering digunakan oleh guru pada saat mengajar adalah dengan menggunakan metode konvensional atau dengan metode ceramah. Artinya guru harus memilih model, metode pendekatan, strategi maupun teknik pembelajaran yang dapat menciptakan kondisi-kondisi yang akan memunculkan aspek-aspek kognitif pada diri siswa (Afriansyah, 2016), salah satunya memunculkan kemampuan representasi. Salah satu pendekatan pada pembelajaran matematika yang dapat membantu dan meningkatkan kemampuan representasi matematis siswa SMP, yaitu dengan pendekatan induktif (Sumaryati, 2013).
Yamin (2012) mengemukakan bahwa pendekatan induktif diawali dengan pemberian berbagai kasus, fakta contoh sehingga dapat mencerminkan suatu konsep atau prinsip, kemudian siswa dibimbing untuk berusaha keras mensistensiskan, mengumumkan, atau menyimpulkan prinsip dasar dari pelajaran tersebut. Sagala (2018) mengatakan bahwa yang diperlukan dalam mengajar secara induktif yaitu ada empat langkah. Kesimpulan dari empat langkah tersebut diantaranya : (1) Memilih dan menentukan bagian dari pengetahuan konsep dan aturan umum tentang persamaan linear satu variabel sebagai pokok bahasan yang akan diajarkan; (2) Menyajikan contohcontoh terlebih dahulu yang spesifik dari konsep, prinsip atau aturan umum pada materi persamaan linear satu variabel sehingga memungkinkan siswa menyusun hipotesis (jawaban sementara) yang bersifat umum; (3) Siswa diberikan contoh tambahan dengan bukti-bukti penyelesaian dari contoh tambahan tersebut dengan tujuan untuk membenarkan atau menyangkal hipotesis yang dibuat siswa; (4) Kemudian siswa menyusun kesimpulan misalnya berupa aturan umum yang telah terbukti berdasarkan langkah-langkah tersebut.

Selain itu, siswa juga membutuhkan bahan ajar untuk membantu proses belajarnya (Nurhikmayati \& Jatisunda, 2019). Chomsin dan Jasmadi (2008) mengemukakan bahwa bahan ajar termasuk seperangkat sarana atau alat pembelajaran yang memuat materi 309 
pembelajaran, metode, dan cara mengevaluasi yang didesain secara sistematis dan menarik untuk mencapai tujuan yang diharapkan. Tujuan yang diharapkan dalam bahan ajar diantaranya mencapai kompetensi atau subkompetensi dengan segala kompleksitasnya (Hernandes, Isnaini, \& Testiana, 2016). Hamdani (2011) mengemukakan bahan ajar adalah seperangkat materi yang telah disusun dengan sistematis, secara tertulis maupun tidak tertulis sehingga membantu siswa untuk belajar.

Berdasarkan pendapat tersebut dapat disimpulkan bahwa bahan ajar adalah rancangan materi pembelajaran yang dibuat oleh guru untuk membantu siswa dalam melaksanakan proses belajar di kelas sehingga siswa dapat memahami materi dalam bahan ajar, materi tersebut bisa berupa tertulis maupun tak tertulis (Nasution, Nasution, \& Haryati, 2017). Dan bahan ajar yang akan dikembangkan adalah bahan ajar berupa modul. Dan dari beberapa uraian tersebut peneliti bertujuan untuk mengembangkan sebuah bahan ajar dengan pendekatan induktif untuk meningkatkan kemampuan representasi matematis siswa SMP.

\section{Metode}

Penelitian ini adalah penelitian dan pengembangan yang mengacu pada model ADDIE. Sugiyono (2015) mengemukakan bahwa metode penelitian dan pengembangan (R\&D) merupakan suatu metode penelitian untuk 310 menghasilkan produk baru, menguji keefektifan produk yang telah ada, serta mengembangkan dan menciptakan produk baru. Dalam penelitian ini, hanya dibatasi sampai tahap ADD dan diujicobakan secara uji coba terbatas. Alur penelitian pada tahapan model ADDIE disajikan dalam gambar 2.

Peneliti melakukan sebuah penelitian di SMP Negeri 1 Tengahtani yaitu siswa kelas VII A. Menggunakan teknik pengumpulan data gabungan (triangulasi).

Untuk menentukan validasi pada modul dan pedoman pembelajaran guru dilihat dari validasi ahli. Perhitungan validasi

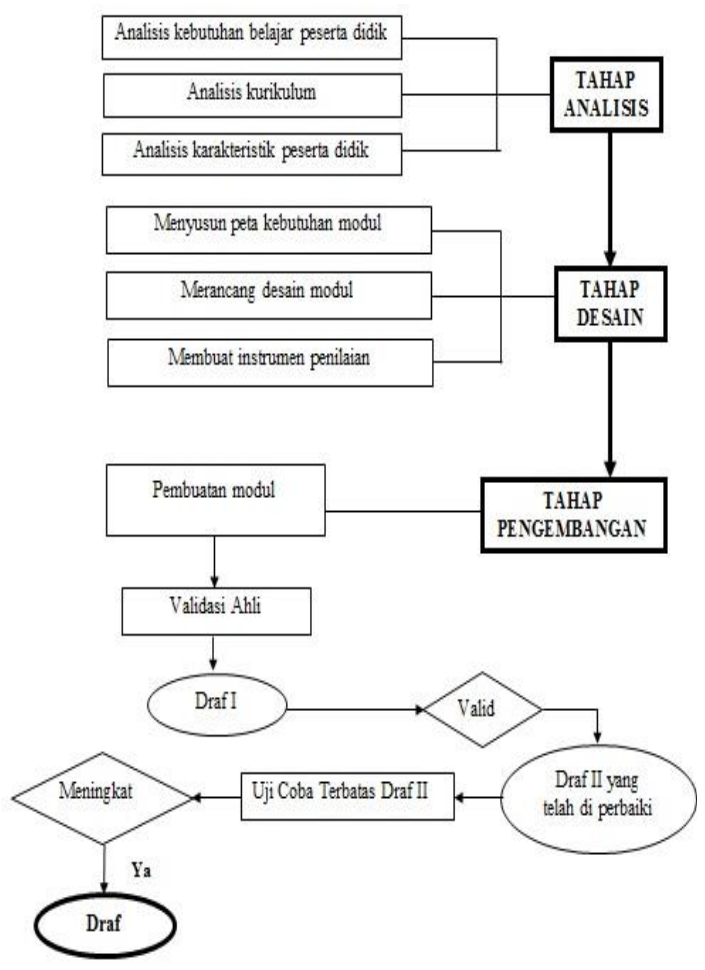

Gambar 2. Alur Penelitian.

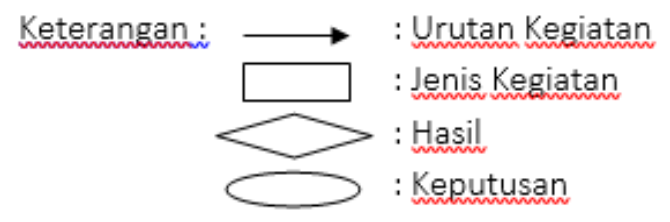

Mosharafa: Jumal Pendidikan Matematika Volume 8, Nomor 2, Mei 2019 Copyright $\odot$ 2019Mosharafa: Jurnal Pendidikan Matematika 
dalam penelitian ini adalah sebagai berikut:

$$
V_{a h}=\frac{T S e}{T S h} \times 100 \%
$$

Keterangan:

$V_{a h} \quad=$ Presentase validasi ahli

TSe = Total skor empirik yang dicapai

TSh = Total skor yang diharapkan

Adapun kriteria yang digunakan untuk menentukan tingkat validasi modul dan pedoman guru oleh ahli (lihat tabel 1).

\section{Hasil dan Pembahasan}

Learning Obstacle (Hambatan Belajar) siswa pada materi persamaan linear satu variabel diperoleh dari hasil ujicoba yang dilakukan di kelas VIII SMP Negeri 1 Tengahtani. Soal yang diberikan berbasis kemampuan representasi matematis yang

Tabel 1.

Kriteria Validitas Modul

\begin{tabular}{|ccl|}
\hline No & Kriteria Validitas & Tingkat Validitas \\
\hline 1. & $85,01 \%-100,00 \%$ & $\begin{array}{l}\text { Sangat valid, } \\
\text { atau dapat } \\
\text { digunakan tanpa } \\
\text { revisi }\end{array}$ \\
\hline 2. & $70,01 \%-85,00 \%$ & $\begin{array}{l}\text { Cukup valid, } \\
\text { atau dapat } \\
\text { digunakan } \\
\text { namun perlu } \\
\end{array}$ \\
& & revisi kecil \\
\hline 3. & $50,01 \%-70,00 \%$ & $\begin{array}{l}\text { Kurang valid, } \\
\text { disarankan tidak } \\
\text { dipergunakan } \\
\text { karena perlu } \\
\end{array}$ \\
& & revisi besar \\
\hline 4. & $01,00 \%-50,00 \%$ & $\begin{array}{l}\text { Tidak valid, atau } \\
\text { tidak boleh } \\
\text { dipergunakan }\end{array}$ \\
\hline
\end{tabular}

Sumber: (Akbar, 2013) berjumlah enam soal, dengan responden 30 siswa (lihat tabel 2).

Berdasarkan tabel 2, Learning Obstacle (Hambatan Belajar) siswa terkait materi persamaan linear satu variabel yang ditemukan adalah hambatan belajar mengenai mengubah masalah yang berkaitan dengan materi persamaan linear satu variabel pada soal menjadi model matematika, hambatan belajar mengenai memahami pengertian persamaan linear satu variabel, hambatan belajar mengenai operasi hitung pada persamaan linear satu variabel, hambatan belajar mengenai mengunakan konsep operasi hitung, hambatan belajar mengenai menyimpulkan pertanyaan yang berkaitan dengan persamaan linear satu variabel,

Tabel 2.

Rekapitulasi Distribusi Hasil Tes Uji Coba No $\begin{gathered}\text { Indikator Kemampuan } \\ \text { Representasi }\end{gathered}$ Matematis

\begin{tabular}{|c|ccc|}
\hline 1 & $\begin{array}{l}\text { Menjawab soal } \\
\text { dengan menggunakan } \\
\text { kata-kata atau teks } \\
\text { tertulis }\end{array}$ & $36,67 \%$ & $63,33 \%$ \\
\hline 2 & $\begin{array}{l}\text { Penyelesaian masalah } \\
\text { dengan melibatkan } \\
\text { ekspresi maematis }\end{array}$ & $43,33 \%$ & $56,67 \%$ \\
\hline 3 & $\begin{array}{l}\text { Penyelesaian masalah } \\
\text { dengan melibatkan } \\
\text { ekspresi maematis }\end{array}$ & $13,33 \%$ & $86,67 \%$ \\
\hline 4 & $\begin{array}{l}\text { Menjawab soal } \\
\text { menggunakan kata- } \\
\text { kata atau teks tertulis }\end{array}$ & $20 \%$ & $80 \%$ \\
\hline 5 & $\begin{array}{l}\text { Menggunakan } \\
\text { representasi visual } \\
\text { untuk menyelesaikan } \\
\text { masalah }\end{array}$ & $26,67 \%$ & $73,33 \%$ \\
\hline 6 & $\begin{array}{l}\text { Menggunakan } \\
\text { representasi visual } \\
\text { untuk menyelesaikan } \\
\text { masalah }\end{array}$ & $16,67 \%$ & $83,33 \%$ \\
\hline
\end{tabular}


hambatan belajar mengenai menuliskan rumus keliling persegi untuk mencari nilai variabel, hambatan belajar mengenai memahami pernyataan soal bahwa lebar dari sebuah persegi panjang itu $6 \mathrm{~cm}$ lebih pendek dari panjangnya, dan hambatan belajar mengenai menuliskan rumus keliling persegi panjang untuk mencari nilai variabel.

Pengembangan bahan ajar berupa modul yang dilakukan penelitian menggunakan model ADDIE yang dibatasi menjadi ADD (Analysis, Design, Develompment).

1. Tahap analisis (Analysis)

Pada tahap ini peneliti menganalisis kebutuhan peserta didik. Tahap analisis kebutuhan peserta didik ini merupakan salah satu cara untuk mengetahui kesulitan belajar yang dialami oleh peserta didik. Pada tahap ini peneliti menganalisis kebutuhan peserta didik melalui tes uji coba awal. Hasil dari tes tersebut menunjukan bahwa siswa masih kesulitan dalam memahami persamaan linear satu variabel dengan melihat learning obstacle peserta didik.

Setelah itu, peneliti menganalisis kurikulum yang digunakan di SMP Negeri 1 Tengahtani. Berdasarkan hasil wawancara dengan seorang guru matematika peneliti mengetahui bahwa di SMP Negeri 1 Tengahtani menggunakan kurikulum 2013.

Selanjutnya peneliti menganalisis karakteristik peserta didik. Peneliti mengamati bagaimana karakteristik peserta didik terhadap pembelajaran matematika saat mengerjakan soal uji coba. Siswa mampu memberikan semangat kepada dirinya sendiri. Karena saat siswa diberikan soal uji coba awal pada pembelajaran matematika maka siswa tersebut mengerjakan .

2. Tahap Desain (Design)

Pada tahap desain ini peneliti melakukan proses perancangan yang meliputi menyusun peta kebutuhan modul, merancang desain modul, dan membuat instrumen penilaian.

Dalam kegiatan menyusun kebutuhan modul, peneliti menyusun materi menjadi dua bagian yaitu materi prasyarat dan materi inti. Untuk materi prasyarat belajar, terdapat materi bentuk aljabar, contoh-contoh bentuk aljabar, dan soal-soal latihan yang dapat dikerjakan oleh siswa. materi prasyarat belajar hanya sebagai materi pengingat atau materi prasyarat untuk mempelajari materi inti. Setelah itu, peneliti menyusun materi persamaan linear satu variabel sebagai materi inti berdasarkan KD dan Indikator pencapaian kompetensi di kurikulum 2013 (Rizkianto \& Santosa, 2017).

Dalam merancang desain modul, peneliti mengumpulkan bahan ajar yang digunakan di sekolah sebagai acuan peneliti untuk mengembangkan modul. Modul yang dikembangkan memuat pendekatan induktif dan kemampuan representasi matematis. 
3. Tahap pengembangan (Development) Dalam tahap pengembangan, peneliti mewujudkan hasil perancangan yang telah dirancang pada tahap desain menjadi sebuah produk berupa modul. Kemudian modul yang sudah dibuat tersebut dikonsultasikan terhadap dosen pembimbing. Dan setelah itu, peneliti melakukan dua hal yaitu validasi dan revisi terhadap modul yang dikembangkan.

Tujuan dilakukannya validasi adalah untuk memperoleh penilaian, masukan, dan saran untuk perbaikan dan penyempurnaan modul. Selain modul, pedoman pembelajaran guru juga dilakukan validasi.

Setelah dilakukan validasi, selanjutnya peneliti melakukan revisi sesuai dengan saran yang telah diberikan oleh validator. Revisi dilakukan untuk penyempurnaan modul yang telah dirancang.

Setelah modul dikembangkan dengan model ADDIE, peneliti juga membuat pedoman pembelajaran guru. Modul dan pedoman pembelajaran guru ini divalidasi oleh 2 Dosen Prodi FKIP Matematika Unswagati Cirebon, 3 guru matematika SMPN 1 Tengahtani. Adapun hasil yang diperoleh dari perhitungan persentasi validasi dari setiap validator ahli (lihat tabel 3). Berdasarkan tabel 3, hasil validasi modul dari kelima validator diperoleh persentase 93,75\% dengan interpretasi sangat valid.
Berdasarkan hasil validasi pedoman pembelajaran guru dari kelima validator diperoleh persentase $89 \%$ dengan interpretasi sangat valid (lihat tabel 4). Sedangkan, penilaian dari setiap validator terdapat komentar dan saran oleh karena itu untuk menyeragamkan pendapat dari semua validator yaitu dilakukan uji $Q$ Cochran, uji ini digunakan untuk menguji perbedaan pendapat dari berbagai para ahli. Berdasarkan $\mathrm{dk}=\mathrm{k}-1=5-1=$ 4 dengan taraf kesalahan 5\% maka harga Tabel 3.

\begin{tabular}{|c|c|c|c|c|}
\hline No & Validator & $\begin{array}{l}\text { KriteriaV } \\
\text { alidasi }\end{array}$ & $\begin{array}{c}\text { KriteriaK } \\
\text { eselu- } \\
\text { ruhan }\end{array}$ & $\begin{array}{l}\text { Inter- } \\
\text { pretasi } \\
\text { Keselu- } \\
\text { ruhan }\end{array}$ \\
\hline 1 & $\begin{array}{c}\text { Validator } \\
1\end{array}$ & $88,75 \%$ & $93,75 \%$ & $\begin{array}{c}\text { Sangat } \\
\text { Valid }\end{array}$ \\
\hline 2 & $\begin{array}{c}\text { Validator } \\
2 \\
\end{array}$ & $95,00 \%$ & & \\
\hline 3 & $\begin{array}{c}\text { Validator } \\
3 \\
\end{array}$ & $87,50 \%$ & & \\
\hline 4 & $\begin{array}{c}\text { Validator } \\
4\end{array}$ & $87,50 \%$ & & \\
\hline 5 & $\begin{array}{c}\text { Validator } \\
5\end{array}$ & $87,50 \%$ & & \\
\hline
\end{tabular}

Tabel 4.

Hasil Validasi Pedoman Pembelajaran Guru Secara Keseluruhan

\begin{tabular}{|ccccc}
\hline No & Validator & $\begin{array}{c}\text { KriteriaV } \\
\text { alidasi }\end{array}$ & $\begin{array}{c}\text { Kriteriak } \\
\text { eselu- } \\
\text { ruhan }\end{array}$ & $\begin{array}{c}\text { Inter- } \\
\text { pretasi } \\
\text { Keselu- } \\
\text { ruhan }\end{array}$ \\
\hline 1 & $\begin{array}{c}\text { Validator } \\
1\end{array}$ & $86,66 \%$ & $89 \%$ & $\begin{array}{c}\text { Sangat } \\
\text { Valid }\end{array}$ \\
\hline 2 & $\begin{array}{c}\text { Validator } \\
2\end{array}$ & $93,33 \%$ & & \\
\cline { 1 - 2 } 3 & $\begin{array}{c}\text { Validator } \\
3\end{array}$ & $88,33 \%$ & \\
\hline 4 & $\begin{array}{c}\text { Validator } \\
4\end{array}$ & $88,33 \%$ & \\
\cline { 1 - 2 } 5 & $\begin{array}{c}\text { Validator } \\
5\end{array}$ & $88,33 \%$ & \\
\end{tabular}


Chi Kuadrat tabel $=9,488$. Bahan ajar siswa berupa modul diperoleh harga Q hitung $(6,66)$, dan pedoman untuk guru diperoleh harga $Q$ hitung $(6,66)$ ternyata dari kedua penilaian tersebut lebih kecil dari $\mathrm{Q}$ tabel $(9,488)$ jadi $\mathrm{H}_{0}$ diterima dan $\mathrm{H}_{1}$ ditolak. Ini berarti tidak terdapat perbedaan pendapat dari para ahli yang signifikan, sehingga dapat dinyatakan bahwa kelima validator memberikan pendapat dan penilaian yang seragam terhadap bahan ajar berupa modul dan pedoman untuk guru yang disusun oleh peneliti.

Sebelum melakukan perhitungan uji gain ternormalisasi, data yang digunakan harus berdistribusi normal. Hasil dari uji ternormalisasi data nilai pretest dan posttest pada kemampuan representasi matematis siswa dilakukan dengan uji shapiro-wilk, diperoleh nilai signifikan shapiro-wilkpretest 0,13>0,05 dan nilai signifikan shapiro-wilk posttest 0,16 > 0,05 , maka $\mathrm{H}_{0}$ diterima dan $\mathrm{H}_{1}$ ditolak yang artinya data nilai pretest dan posttest kemampuan representasi matematis siswa berdistribusi normal (lihat tabel 5).

Dari 30 siswa hanya ada 18 siswa yang memperoleh interpretasi sedang, dan 12 siswa memperoleh interpretasi rendah. Secara keseluruhan, terdapat peningkatan kemampuan representasi matematis siswa dengan menggunakan modul. Hal ini terlihat dari data gain sebesar 0,37 dengan interpretasi sedang dari rata-rata nilai pretes dan rata-rata nilai posttest masingmasing 18,57 dan 48,63 (lihat tabel 6).
Berdasarkan penelitian pengembangan

Tabel 5.

Hasil Uji Gain Ternormalisasi Tes Kemampuan Representasi Matematis Siswa

\begin{tabular}{|c|c|c|c|c|}
\hline \multicolumn{4}{|c|}{ Kelas Eksperimen } & \multirow{2}{*}{ 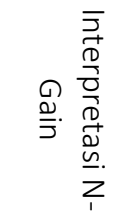 } \\
\hline Subjek & $\begin{array}{l}\text { Pre- } \\
\text { test }\end{array}$ & $\begin{array}{c}\text { Post- } \\
\text { test }\end{array}$ & $\begin{array}{c}\mathrm{N}- \\
\text { Gain }\end{array}$ & \\
\hline S-1 & 19 & 54 & 0,43 & Sedang \\
\hline S-2 & 13 & 39 & 0,30 & Sedang \\
\hline S-3 & 11 & 49 & 0,43 & Sedang \\
\hline S-4 & 31 & 65 & 0,49 & Sedang \\
\hline S-5 & 4 & 25 & 0,22 & Rendah \\
\hline S-6 & 21 & 53 & 0,41 & Sedang \\
\hline S-7 & 13 & 50 & 0,43 & Sedang \\
\hline$S-8$ & 34 & 60 & 0,39 & Sedang \\
\hline S-9 & 27 & 48 & 0,29 & Rendah \\
\hline S-10 & 13 & 30 & 0,20 & Rendah \\
\hline S-11 & 27 & 54 & 0,37 & Sedang \\
\hline S-12 & 25 & 65 & 0,53 & Sedang \\
\hline S-13 & 13 & 61 & 0,55 & Sedang \\
\hline S-14 & 21 & 50 & 0,37 & Sedang \\
\hline S-15 & 36 & 54 & 0,28 & Rendah \\
\hline S-16 & 20 & 51 & 0,39 & Sedang \\
\hline S-17 & 13 & 55 & 0,48 & Rendah \\
\hline S-18 & 27 & 70 & 0,59 & Sedang \\
\hline S-19 & 27 & 48 & 0,29 & Rendah \\
\hline S-20 & 9 & 44 & 0,38 & Sedang \\
\hline$S-21$ & 11 & 40 & 0,33 & Rendah \\
\hline$S-22$ & 6 & 20 & 0,15 & Rendah \\
\hline S-23 & 16 & 25 & 0,11 & Rendah \\
\hline S-24 & 12 & 60 & 0,55 & Sedang \\
\hline S-25 & 17 & 61 & 0,53 & Sedang \\
\hline S-26 & 35 & 75 & 0,62 & Sedang \\
\hline S-27 & 13 & 35 & 0,25 & Rendah \\
\hline S-28 & 20 & 70 & 0,63 & Sedang \\
\hline S-29 & 12 & 25 & 0,15 & Rendah \\
\hline S-30 & 11 & 23 & 0,13 & Rendah \\
\hline Jumlah & 557 & 1459 & 11,24 & \\
\hline rata- & 18,57 & 48,63 & 0,37 & Sedang \\
\hline
\end{tabular}

Volume 8, Nomor 2, Mei 2019

Copyright $\odot$ 2019Mosharafa: Jurnal Pendidikan Matematika 
bahan ajar dengan pendekatan induktif untuk meningkatkan kemampuan representasi matematis siswa SMP yang telah dilakukan oleh peneliti, maka didapatkan beberapa simpulan yaitu Learning obstacle (Hambatan Belajar) siswa terkait materi persamaan linear satu variabel yang ditemukan adalah hambatan belajar mengenai mengubah masalah yang berkaitan dengan materi persamaan linear satu variabel kelas VII SMP Negeri 1 Tengahtani pada soal menjadi model matematika, hambatan belajar mengenai memahami pengertian persamaan linear satu variabel, hambatan belajar mengenai operasi hitung pada persamaan linear satu variabel, hambatan belajar mengenai menggunakan konsep operasi hitung, hambatan belajar mengenai menyimpulkan pernyataan yang berkaitan dengan persamaan linear satu variabel, hambatan belajar mengenai menuliskan rumus keliling persegi untuk mencari nilai variabel, hambatan belajar mengenai memahami pernyataan soal bahwa lebar dari sebuah persegi panjang itu $6 \mathrm{~cm}$ lebih pendek dari panjangnya, dan hambatan belajar mengenai menuliskan rumus keliling persegi panjang untuk mencari

Tabel 6.

Hasil Rekapitulasi Uji Gain Ternormalisasi yang Dicapai Oleh Siswa

\begin{tabular}{|llc|}
\hline No & Interpretasi Peningkatan & $\begin{array}{c}\text { Jumlah } \\
\text { Siswa }\end{array}$ \\
\hline 1. & Tinggi & 0 \\
\hline 2. & Sedang & 18 \\
\hline 3. & Rendah & 12 \\
\hline 4. & TidakTerjadiPeningkatan & 0 \\
\hline 5. & TerjadiPenurunan & 0 \\
\hline
\end{tabular}

nilai variabel. Selain itu, didapat kesimpulan bahwa hasil validasi modul dan pedoman pembelajaran guru dapat dinyatakan bahwa kevalidan adalah 93,75\% dan 89\% dengan kriteria sangat valid. Dan hasil uji Q cochran harga Q hitung masing-masing adalah 6,66 yang berarti tidak ada perbedaan yang signifikan dari kelima validator. Dari 30 siswa hanya ada 18 siswa yang memperoleh interpretasi sedang dan 12 siswa memperoleh interpretasi rendah. Secara keseluruhan, bahan ajar berupa modul ini dapat meningkatkan kemampuan representasi matematis siswa, sejalan dengan penelirian Ramziah (2016); dan Annajmi dan Afri (2019), dengan nilai gain sebesar 0,37 maka peningkatan tersebut tergolong pada kriteria sedang.

\section{Penutup}

Berdasarkan simpulan hasil penelitian dan pembahasan maka disarankan, hambatan belajar yang diamati peneliti hanya menggunakan sampel kecil yang tidak terlalu banyak. Oleh karena itu, peneliti menyarankan untuk menganalisis hambatan belajar siswa dengan lebih luas ruang lingkupnya. Hasil penelitian pengembangan bahan ajar dengan pendekatan induktif dapat dijadikan sebagai salah satu bahan ajar khusus pada materi persamaan linear satu Variabel. Namun, jika bahan ajar ini diimplementasikan harus sesuai dengan karakteristik siswa. Tahapan model ADDIE dalam penelitian ini hanya dilakukan pada

Mosharafa: Jumal Pendidikan Matematika 315

Volume 8, Nomor 2, Mei 2019

Copyright $\odot$ 2019Mosharafa: Jurnal Pendidikan Matematika 
tahap pengembangan (Development). Oleh karena itu, peneliti menyarankan pada penelitian selanjutnya dilakukannya sampai pada tahap evaluasi (Evaluation).

\section{Daftar Pustaka}

Afriansyah, E. A. (2016b). Makna Realistic dalam RME dan PMRI. LEMMA, I/(2), 96-104.

https://doi.org/10.22202/il.2016.v2i 2.578

Akbar, S. (2013). Instrumen Perangkat Pembelajaran. Bandung: PT Remaja Rosdakarya.

Annajmi, A. \& Afri, L. E. (2019). Pengaruh Penggunaan Lembar Aktivitas Siswa Berbasis Metode Penemuan Terbimbing terhadap Peningkatan Kemampuan Representasi Matematis Siswa. Mosharafa: Jurnal Pendidikan Matematika, 8(1), 95106.

Chomsin, W. S. \& Jasmadi. (2008). Panduan menyusun bahan ajar berbasis kompetensi. Jakarta: PT. Elex Media Komputindo.

Effendi, L.A. (2012). Pembelajaran Matematika Dengan Metode Penemuan Terbimbing Untuk Meningkatkan Kemampuan Representasi Dan Pemecahan Masalah Matematis Siswa SMP. Jurnal Penelitian Pendidikan vol.13, No. 2, Oktober 2012.

Ferdianto, F. (2015). Media Audio Visual pada Kemampuan Komunikasi

Matematis Siswa Kelas XI. Jurnal Euclid, Vol. 2, No. 2, PP.251-365.

Hamdani. (2011). Strategi Belajar Mengajar. Bandung: Pustaka setia.

Hernandes, V., Isnaini, M., \& Testiana, G. (2016). Pengembangan Bahan Ajar Matematika Menggunakan Komputer pada Materi Kesebangunan di Kelas IX MTs Negeri 1 Palembang. Mosharafa: Jurnal Pendidikan Matematika, 5(3), 281-292.

Hutagaol, Kartini. (2013). Pembelajaran Kontekstual untuk Meningkatkan Kemampuan Representasi Matematis Sekolah Menengah Pertama. Jurnal IImiah Progam Studi Matematika STKIP Siliwangi Bandung. Volume 2.

Mandur, K. (2013). Kontribusi Kemampuan Koneksi, Kemampuan Representasi, dan Disposisi Matematis terhadap Prestasi Belajar Matematika Siswa SMA di Kabupaten Manggarai. Ejournal Progam Pascasarjana Universitas Pendidikan Ganesha Program Studi Matematika, Volume 2.

Nasution, M. D., Nasution, E., Haryati, F. (2017). Pengembangan Bahan Ajar Metode Numerik dengan Pendekatan Metakognitif Berbantuan MATLAB. Mosharafa: Jurnal Pendidikan Matematika, 6(1), 69-80.

Nurhikmayati, I., \& Jatisunda, M. G. (2019). Pengembangan Bahan Ajar Matematika Berbasis Scientific yang 
Berorientasi pada Kemampuan

Berpikir Kritis Matematis Siswa.

Mosharafa: Jurnal Pendidikan

Matematika, 8(1), 49-60.

Ramziah, S. (2016). Peningkatan

Kemampuan

Representasi

Matematis Siswa Kelas X2 SMAN 1

Gedung Meneng Menggunakan

Bahan Ajar Matriks Berbasis

Pendekatan Saintifik. Mosharafa:

Jurnal Pendidikan Matematika, 5(2),

138-147.

Rizkianto, I., \& Santosa, R. H. (2017).

Analisis Buku Matematika Siswa SMP

Kurikulum 2013. Mosharafa: Jurnal

Pendidikan Matematika, 6(2), 229236.

Sagala, D. D. (2018). Pengaruh Model

Pembelajaran Creative Problem

Solving dengan Strategi

Pembelajaran Induktif terhadap

Hasil Belajar Akuntansi Siswa Kelas

Xii Akuntansi SMK Negeri 7 Medan

T.P 2018/2019. Undergraduate

thesis, UNIMED.

Sugiyono. (2015). Metodologi Penelitian

Pendidikan. Bandung: Alfabeta.

Sumaryati, E. (2013). Pendekatan Induktif-

Deduktif Disertai Strategi Think-Pair-

Square-Share untuk Meningkatkan

Kemampuan Pemahaman dan

Berpikir Kritis serta Disposisi

Matematis Siswa SMA. Infinity

Journal, 2(1), 26-42.

Yamin, M. (2012). Strategi Pembelajaran

Berbasis Kompetensi. Jakarta:

Referensi (GP Press Group).

\section{Riwayat Hidup PENULIS}

Indri Puspandari, S.Pd., MOS.

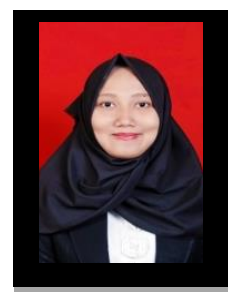

Lahir di Cirebon pada tanggal 25 juni 1996. Pada tahun 2014 melanjutkan di perguruan tinggi, tepatnya di Universitas Swadaya Gunung Jati Cirebon pada Program Studi Pendidikan Matematika. Penulis menyelesaikan kuliah strata satu (S1) pada tahun 2018 dengan skripsi yang berjudul "Pengembangan Bahan Ajar dengan Pendekatan Induktif untuk Meningkatkan Kemampuan Representasi Matematis Siswa SMP”.

\section{Dr. H. Ena Suhena, M.Pd.}

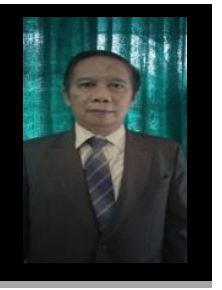

Lahir di Majalengka, 31 Mei 1957. Pada tahun 1982 lulus mengikuti Program Sarjana Program Studi Pendidikan Matematika di Universitas Pendidikan Indonesia. Pada tahun 2001 lulus dari program Magister (S2) dari Program Studi Pendidikan Matematika Universitas Pendidikan Indonesia. Pendidikan terakhir lulus program doctor (S3) pada tahun 2009 dari Program Studi Pendidikan Matematika Universitas Pendidikan Indonesia.

\section{Fahrudin Muhtarulloh, S.Si., M.Sc., MOS.}

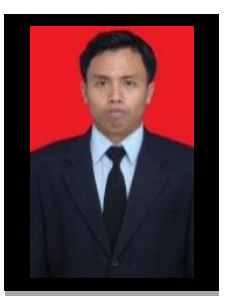

Lahir di Majalengka, 9 Januari 1986. Pada tahun 2008 lulus mengikuti Program Sarjana pada FPMIPA Program Studi Matematika di Universitas Pendidikan Indonesia. Pendidikan terakhir lulus pada tahun 2013 dari Universitas Gadjah Mada Program Studi S-2 Matematika. 
This page is intentionally left blank 